\title{
Holmes se Apostoliese VAders in Grieks en ENGELS - 'N MOET VIR ELKE BOEKRAK
}

\section{Book Title:}

The Apostolic Fathers:

Greek Texts and English

Translation

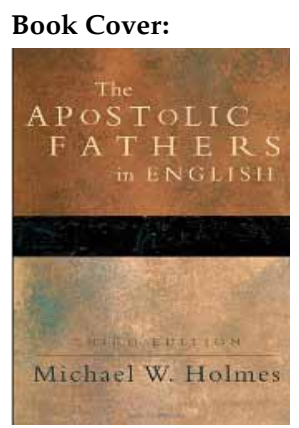

Author:

Michael W. Holmes

ISBN:

978-0-8010-3468-8

\section{Publisher:}

Baker Academic (a division of Baker Publishing Group), Michigan; 2007, p. 832, \$45.00* *Book price at time of Review

\section{Review Title:}

Holmes se Apostoliese

Vaders in Grieks en Engels -

'n moet vir elke boekrak

\section{Reviewer:}

Lambert D. Jacobs

\section{Affiliation:}

${ }^{1}$ Departement Ou en Nuwe

Testament, Universiteit

Stellenbosch

\section{email:}

lam.isjacobs@yahoo.com

\section{Postal address:}

Posbus 415, Wellington 7654, Suid-Afrika

\section{How to cite this book} review:

Lambert, D.J., 2010, 'Holmes se Apostoliese Vaders in Grieks en Engels - 'n moet vir elke boekrak', Verbum et Ecclesia 31(1), Art. \#404, 1 page. DOI: 10.4102/ve.v31i1.404

\section{This review is available} at:

http://www.ve.org.za

(c) 2010. The Authors. Licensee: OpenJournals Publishing. This work is licensed under the Creative Commons Attribution License.
Daar is waarskynlik bitter min tekste in die teologiese wêreld met 'n langer Wirkungsgeschichte as die diglot-teks in Grieks (en Latyn) en Engels van die Apostoliese vaders deur die groot Engelse geleerde Joseph Barber Lightfoot (1828-1889), 'n voormalige Hulsean- en Lady Margaret-professor in Godgeleerdheid aan Cambridge, en later biskop van Durham. Hierdie teks is finaal geredigeer en afgerond deur sy jonger kollega J.R. Harmer, waarna Macmillan in Londen dit in 1891 (twee jaar ná Lightfoot se dood) gepubliseer het. Die teks wat hier bespreek word, is op dié oerteks van Lightfoot en Harmer gegrond.

Die redakteur en vertaler van dié bundel is Michael W. Holmes (PhD, Princeton-kweekskool), professor in Bybelkunde en Vroeë Christendom aan Bethel College in St Paul, Minnesota. Holmes het hierdie uitgawe aan sy eie vader sowel as sy Doktorvater, die bekende Bruce M. Metzger, opgedra wat kort ná mekaar oorlede is. Dr Holmes was ook verantwoordelik vir die kommentaar op 1 en 2 Tessalonisense in die NIV Application Commentary-reeks, en is tans besig met kritiese kommentaar op Polikarpus se Brief aan die Filippense en Die martelaarskap van Polikarpus.

Baker Book House het Holmes in die 1980's genader om Lightfoot en Harmer se magistrale werk te hersien. Dit het eers op ' $n$ tweede uitgawe van die oorspronklike Engelse vertaling in 1989 uitgeloop. Daarna is die Griekse en Latynse tekste ook hersien en bygewerk, en het dit in 1992 as die tweede uitgawe van Lightfoot en Harmer se diglot, en die eerste uitgawe deur Holmes, die lig gesien. Daardie uitgawe is nogmaals effens gekorrigeer en hersien, en in 1999 in sagteband uitgegee.

In 2003 het die Baker Academic-uitgewers Holmes weer vir 'n grondige hersiening van die Engelse teks genader. Die idee was om 'n meer gebruikersvriendelike teks vir voorgraadse studente en algemene lesers te bied.

Saam met die hersiening van die Engelse teks is 'n grondige nasien van die Griekse en Latynse tekste ook van stapel gestuur. Buiten die Grieks en Latyn bevat die boek ook Armeense, Siriese en Arabiese tekste van sommige van die Papiasfragmente. Die tekskritiese apparaat is grondig hersien, en meer as 200 nuwe tekskritiese notas is bygevoeg. Afgesien van hierdie veranderinge aan die teks, vertaling en notas, het Holmes ook die inleidings tot al die geskrifte in die bundel met bygewerkte besprekings van teksgetuies en -probleme uitgebrei. Die bibliografieë by elkeen van die geskrifte is ook heelwat uitgebrei, en sluit nou ál die klassieke werke sowel as die mees onlangse bronne in. Verwysings na artikels uit Paul Foster se versamelwerk The writings of the Apostolic Fathers (2007) duik op 'n paar plekke op, terwyl Alan Brent se 2006-bron Ignatius of Antioch and the Second Sophistic ook in die bibliografie by Ignatius genoem word. Beter bygewerk kan ' $n$ mens beswaarlik kry. Dit is ook indrukwekkend dat minstens een internasionale geleerde nie skroom om Suid-Afrikaanse bronne te raadpleeg nie. Om die waarheid te sê word nie minder nie as agt publikasies van Jonathan Draper in die bibliografie by die Didache gelys - ook ' $n$ aanduiding van die gesag waarmee Draper oor die Didache praat. Cilliers Breytenbach en Laurence Welborn se boek uit 2004, Encounters with Hellenism: Studies on the First Letter of Clement, pryk ook tussen 1 Klemens se bronne.

Agterin die boek is heelwat nuttige naslaanhulp, waaronder ' $n$ tematiese ontleding van die Apostoliese vaders, ' $n$ onderwerpindeks oor die inleidings en notas, ' $n$ indeks van moderne outeurs, en ' $n$ indeks van antieke bronne. Daarbenewens is daar kaarte wat Ignatius se roete en die verspreiding van die Christendom aandui.

Die boek is netjies in ' $\mathrm{n}$ stewige Baladek-hardeband gebind, met 'n goue pleklint om naslaan te vergemaklik. Omvangryke publikasies is altyd ' $n$ uitdaging, maar die uitgewers het daarin geslaag om die 832 bladsye saam te voeg sonder dat die boek lomp en swaar voorkom.

Die resensies wat al oor hierdie uitgawe verskyn het, is vol lof. Van die resensente, soos Randall Buth en Paul Foster, meen dat 'n mens dié een op jou rak wíl hê, selfs al besit jy ' $n$ vorige uitgawe. Ek stem heelhartig saam, en onderskryf Scot McKnight se mening op sy webtuiste: 'I have to...give top billing to Michael Holmes' new handy Greek-English edition of the apostolic fathers. Simply a must.' 